\title{
The Influence of Caffeine and Thymol on the Survival, Growth and Reproduction of Subulina octona (Brugüière, 1789) (Mollusca, Subulinidae)
}

\author{
Paula Ferreira ${ }^{1}$, Geraldo Luiz Gonçalves Soares $^{2}$, Sthefane D'ávila ${ }^{1,3}$ and Elisabeth \\ Cristina de Almeida Bessa ${ }^{1,4^{*}}$ \\ ${ }^{1}$ Laboratório de Biologia de Moluscos e Helmintos; Departamento de Zoologia; Instituto de Ciências Biológicas; \\ Universidade Federal de Juiz de Fora; Juiz de Fora - MG - Brasil. ${ }^{2}$ Departamento de Botânica; Instituto de \\ Biociências; Universidade Federal do Rio Grande do Sul; Porto Alegre - RS - Brasil. ${ }^{3}$ Universidade Federal Rural \\ do Rio de Janeiro; Seropédica - RJ - Brasil. ${ }^{4}$ Departamento de Zoologia; Instituto de Ciências Biológicas; \\ Universidade Federal de Juiz de Fora Juiz de Fora - MG - Brasil
}

\begin{abstract}
Subulina octona is a terrestrial snail which serves as an intermediate host for the parasites. It is also an agricultural pest. The aim of this work was to assess, during 120 days, the effects of caffeine and thymol at $2.5 \mathrm{~g} / \mathrm{L}$ and $5 \mathrm{~g} / \mathrm{L}$ on the hatchability, survival after hatching, growth and reproduction of S. octona under the laboratory conditions. A total of 240 eggs, 240 juveniles aged 10-day-old, and 240 aged 30-day-old were tested. The results showed that thymol (at $2.5 \mathrm{~g} / \mathrm{L}$ and $5 \mathrm{~g} / \mathrm{L}$ ) and caffeine (at $5 \mathrm{~g} / \mathrm{L}$ ) acted as ovicides. In the 10-day-old juveniles, caffeine at $5 \mathrm{~g} / \mathrm{L}$ caused $25 \%$ mortality and at $2.5 \mathrm{~g} / \mathrm{L}$ it caused $30 \%$ mortality. Thymol at 2.5 and $5 \mathrm{~g} / \mathrm{L}$ caused 20 and $22.5 \%$ mortality, respectively. In the 30-day-old juveniles, caffeine at 5 g/L caused $47.5 \%$ mortality.
\end{abstract}

Key words: Caffeine, Thymol, molluscicide, Subulina octona, snail-terrestrial

\section{INTRODUCTION}

Some species of terrestrial snails can cause considerable losses, due to the damage they cause to the plantations and by acting as intermediate hosts for helminths. Such species are well adapted to anthropic environments and this makes controlling their population more difficult. For this reason, there is an interest in discovering substances of vegetable origin that have molluscicidal activity and little residual effect on the environment.
Subulina octona (Brugüière, 1879) (Mollusca, Subulinidae) is a terrestrial snail which has a wide geographical distribution, being very frequent in tropical regions (Araújo and Bessa, 1993). It is referred as an intermediate host in the life cycle of Platynosomum illiciens (Braum, 1901) (Digenea, Dicrocoeliidae) (Maldonado, 1945) and of Aelurostrongylus abstrusus (Railliet, 1898) (Nematoda, Angiostrongylidae) (Ash, 1962), both parasites of the domestic cat. It has also been cited as an intermediate host of Tanaisia bragai (Santos, 1934) (Digenea, Eucotylidae) (Maldonado, 1945;

\footnotetext{
* Author for correspondence: elisabeth.bessa@edu.ufjf
} 
Brandolini, 1997), Postharmostomum gallium Witenberg, 1923 (Digenea, Brachylaimidae) (Alicata, 1940; Duarte, 1980), Davainea proglottina (Davaine, 1860) (Cestoda, Davaineidae) (Van Volkenberg, 1937 in Maldonado, 1945), all of which are parasites of birds and of Angiostrongylus vasorum (Baillet, 1866) Kamensky, 1905 (Nematoda, Angiostrongylidae), which is a parasite of canids (Bessa et al., 2000).

Due to the high cost and danger in the use of toxic products to combat the snails, the molluscicidal substances that have vegetable origin can be a safe way of controlling these animals. Vasconcelos et al. (2003) stated that the search for new muluscicids derived from the plant extracts is growing in importance because sintetic products are expensive and present difficulties regarding application and transport.

Caffeine is a nitrogenated secondary metabolite which is present in various species of plants, such as Camellia sinensis (L.) Kuntze (Theaceae), Coffea arabica L. (Rubiaceae), Ilex paraguariensis St. Hil. (Aquifoliaceae) and Paullinia cupana Kunth. (Sapindaceae) (Brenelli, 2003). The molluscicidal and phage inhibitor potential of this substance was observed by Hollingsworth et al. (2002) in controlling the snails of Veronicella cubensis (Pfeiffer, 1840) (Mollusca, Veronicellidae). Thymol is also a vegetable substance, obtained from the essential oil of species of the family Laminacea, such as the Monarda punctata L. (mint), the Thymus vulgaris L. (thyme) and the T. persicus L.. It is found in the products used to combat the microorganisms in oral cavity, acting as a bactericide and a fungicide, and also has anti-inflammatory activity (Budavari, 1989; Wicht et al., 2004; Salgueiro et al., 2003; Okazaki et al., 2002). Bezerra et al. (1981) observed the molluscicidal activity of the thymol present in the essential oil of Lippia graveolens (Kunth) (Verbenaceae) on Biomphalaria spp. Sing et al. (1997) confirmed the molluscicidal activity of thymol on Lymnaea acuminata L., using the fruits of Trachyspermum ammi L. (Apiaceae).

The aim of this work was to assess, during 120 days, the influence of caffeine and thymol on the development of the eggs and on the survival, growth and reproduction of 10-day-old and 30day-old juveniles of the species Subulina octona under the laboratory conditions.

\section{MATERIAL AND METHODS}

The experiments were carried out in the Laboratory of Moluscs and Helminths BiologyPós-Graduação em Comportamento e Biologia Animal, Universidade Federal de Juiz de Fora Juiz de Fora, Minas Gerais, Brasil.

For this study 240 S. octona eggs, 240 juveniles aged 10-day-old and 240 aged 30-day-old were used. The snails were ramdomly distributed in the groups of 10 and kept in terraria in one of two ways: the eggs were put in terraria which were 9 $\mathrm{cm}$ in diameter and $6.2 \mathrm{~cm}$ height; the 10-day-old and the 30-day-old juveniles were put in terraria which were $12 \mathrm{~cm}$ in diameter and $9 \mathrm{~cm}$ height. The terraria contained previously sterilized $\left(120^{\circ} \mathrm{C} / 1 \mathrm{~h}\right)$ humus and were closed with cotton cloth. For the test with the solution of caffeine at $2.5 \mathrm{~g} / \mathrm{L}, 40$ eggs, forty 10-day-old juveniles and forty 30-day-old juveniles were used. The same quantity of the eggs and juveniles were used with the concentrations of caffeine at $5 \mathrm{~g} / \mathrm{L}$, thymol at 2.5 and $5 \mathrm{~g} / \mathrm{L}$ and for the two control groups (one group for the caffeine and another for the thymol control).

The snails were fed a ration composed by $(\%) 22$ crude protein, 2.6 ethereal extract, 6.5 fibrous matter, 9.0 mineral matter, 1.50 calcium and 0.50 phosphorus) sifted with a sieve (1 mm mesh) and enriched with calcium carbonate in a proportion of 3:1 (Bessa and Araújo, 1995a,b) The terraria were moistened with tap water every three days, at which time the snails' food was also renewed.

The minimum and maximum temperatures as well as the relative humidity were measured daily with a thermometer and a thermohygrometer (Incoterm ${ }^{\circledR}$ ).

The caffeine (Nuclear ${ }^{\circledR}$ ) was diluted in distilled water heated to $40^{\circ} \mathrm{C}$ under constant agitation. In order to dilute the thymol (Isofar ${ }^{\circledR}$ ), distilled water heated to $60^{\circ} \mathrm{C}$ with $1 \%$ dimethyl sulfoxide P.A. (Isofar®) (DMSO).

\section{Experiment I - Assessment of the influence of caffeine and thymol on the hatching of offspring from the treated eggs}

To test with caffeine and thymol groups of ten eggs were put in a plastic container, which was 9 $\mathrm{cm}$ in diameter and $6.2 \mathrm{~cm}$ height and then $5 \mathrm{ml}$ of one of the solutions (caffeine and thymol at 2.5 and $5 \mathrm{~g} / \mathrm{L}$ ) were added to the plastic container and 
left for 10 minutes as recommended by Souza (2003).

The caffeine control received distilled water, while the thymol control received distilled water with DMSO at $1 \%$. After 10 minutes, the eggs were taken out of the solution and put back into their respective terraria.

The juveniles that hatched from the eggs were maintained in their terraria for 20 days. The snails which survived these 20 days were used in the next experiment.

Experiment II - Assessment of the survival, growth and reproduction of juveniles hatched from eggs treated with caffeine and thymol at different concentrations

Observations about the survival, growth and reproduction of the $S$. octona juveniles which ecloded from eggs treated with caffeine and thymol were made during 120 days. The growth of the individuals from all the groups was observed by means of biweekly measurements (until their $120^{\text {th }}$ day of life) with a caliper Kanon ${ }^{\circledR}$ (Mardened Stainless $1 / 28$ in $1 / 20 \mathrm{~mm}$ ). The time they took to attain the sexual maturity was also observed. The parameter used to determine when sexual maturity was attained was the presence of the eggs in the terraria. All the eggs found in the terraria until the $120^{\text {th }}$ day were counted.

Experiment III - The influence of caffeine and thymol on the survival, growth and reproduction of 10-day-old and 30-day-old juveniles

In order to carry out the tests with caffeine and thymol, the juveniles were left fasting for $24 \mathrm{~h}$ (Souza, 2003). After this period, they were put, in groups of ten and with the help of a brush, in a plastic container, which was $5 \mathrm{~cm}$ in diameter and $4 \mathrm{~cm}$ height, and they stayed in contact with $5 \mathrm{ml}$ of one of the solutions (caffeine and thymol at 2.5 thymol at 2.5 and $5 \mathrm{~g} / \mathrm{L}$ ) for 10 minutes. The amount of the substance $(5 \mathrm{ml})$ just allowed the contact of the cephalopodal mass of the moluscs, avoiding moluscs' immersion. The caffeine control group was given distilled water, while the thymol control group was given distilled water with DMSO at $1 \%$. After this period, the juveniles were taken out of the solution and put back into their respective terraria.

The survival, growth and reproduction of these moluscs were observed during 120 days. The growth of both the treated individuals and the ones from the control group was assessed every fifteen days until their $120^{\text {th }}$ day of life.

For the statistical analysis of the data, Student's ttest and the analysis of variance (one-way ANOVA) were used, with a confidence interval of 95\%, followed by the Tukey-Kramer test.

\section{RESULTS AND DISCUSSION}

Experiment I - Assessment of the influence of caffeine and thymol on the hatching of offspring from the treated eggs

Caffeine negatively influenced the hatching of the offspring and it acted as an ovicide resulting: 87.5 and $50 \%$ of the eggs treated with caffeine at 5 and $2.5 \mathrm{~g} / \mathrm{L}$, respectively (Table 1 ).

Table 1 - Hatchability of Subulina octona offspring from the eggs treated with caffeine in different concentrations, observed during the 20 days after treatment.

\begin{tabular}{lcc}
\hline Treatment & Hatchability $\mathbf{X} \pm$ SD & Percentual hatching \\
\hline Caffeine 5g/L & $1.25 \pm 2.22^{\mathrm{a}}$ & 12.5 \\
Caffeine 2,5g/L & $5.00 \pm 2.70^{\mathrm{a}, \mathrm{b}}$ & 50.0 \\
Control & $6.00 \pm 0.80^{\mathrm{b}}$ & 60.0 \\
Thymol 5g/L & $0.50 \pm 0.25^{\mathrm{a}}$ & 2.50 \\
Thymol 2,5g/L & $0.50 \pm 0.25^{\mathrm{a}}$ & 2.50 \\
Control & $1.75 \pm 1.20^{\mathrm{b}}$ & 47.5 \\
\hline
\end{tabular}

Values whith unequae letters were significantly different.

These results were important, because they showed that caffeine could help control this species of snail by effectively preventing the completion of the embryonic development of the offspring. Some authors have reported the low effectiveness of molluscicides on the eggs. According to Pereira and Souza (1974), who studied the effects of the hexane extract of the peel 
of the cashew nut on the egg masses of Biomphalaria glabrata Say 1818, the eggs were 10 to 20 times more resistant than the adult individuals. This low susceptibility was also observed by Souza et al. (1987) with the butyl extract of Phytolaca dodecandra L..

The difference between the mean hatching of offspring from the eggs treated with caffeine at 5 and $2.5 \mathrm{~g} / \mathrm{L}$ and the control group was significant (ANOVA $p<0.05 ; p=0.03$ ). The Tukey-Kramer test showed that the difference between the means of the group treated with caffeine at $5 \mathrm{~g} / \mathrm{L}$ and the control group was significant $(\mathrm{p}<0.05)$, while that between the groups treated with caffeine at 2.5 and $5 \mathrm{~g} / \mathrm{L}$, the results were not significant $(\mathrm{p}>0.05)$ (Table 1).

Thymol also had ovicidal activity: $98 \%$ of the eggs treated with thymol at 5 and $2.5 \mathrm{~g} / \mathrm{L}$ did not hatch (Table 1). Hence, thymol could also be used to control the snails by inactivating their eggs, since these animals have a very large reproductive capacity and some of the products in use manage to affect the snail, but not their eggs. Souza et al. (1984) found that of the 159 extracts they tested on the eggs of $B$. glabrata, only 18 had ovicidal activity.

The Tukey-Kramer test showed that the difference between the hatching means of the snails from the group treated with thymol at $5 \mathrm{~g} / \mathrm{L}$ and the control group ( $\mathrm{p}<0.05)$, as well as from the control group and the snails treated with thymol at $2.5 \mathrm{~g} / \mathrm{L}$ ( $p<0.05)$ was significant.

According to Bessa and Araújo (1995a), the eclosion of offspring happens between the first and $15^{\text {th }}$ day after the eggs are laid. These authors worked with 96 eggs and observed wich $94.8 \%$ of viability. The temperatures they registered went from 17 to $26.5^{\circ} \mathrm{C}$. This high rate of egg hatchability was not observed in our experiment, principally in the thymol control group, in which only $47.5 \%$ of the eggs hatched. This data suggested that the eggs were influenced by the DMSO (dimethyl sulfoxide) used in this control group, since the maximum $23.5^{\circ} \mathrm{C}$ and minimum $19.7^{\circ} \mathrm{C}$ temperatures registered were similar to those registered by Bessa and Araújo (1995a).

Experiment II - Assessment of the survival, growth and reproduction of juveniles hatched from eggs treated with caffeine and thymol at different concentrations

The experiments took place from May $17^{\text {th }}$ to September $14^{\text {th }}, 2004$. The maximum temperatures registered during this period was $20.7^{\circ} \mathrm{C}$, the minimum was $17.3^{\circ} \mathrm{C}$, and the relative humidity was $70 \%$. During the 120 days after the treatment, there were differences between the survival mean of the snails which hatched from the eggs treated with caffeine when compared to the mean of the control group (Table 2, Fig. 1).

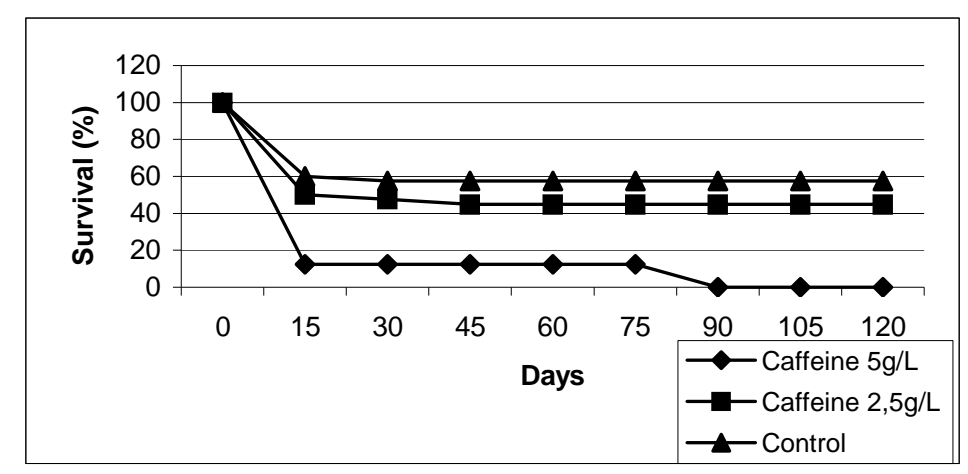

Figure 1 - Survival of Subulina octona juveniles which hatched from eggs treated with caffeine and were observed during 120 days.

Table 2 - Survival of Subulina octona juveniles which hatched from the eggs treated with caffeine in different concentrations, observed during the 120 days following the eclosion.

\begin{tabular}{ccc}
\hline Treatment & Survival $\mathbf{X}_{ \pm}$SD & Percentual Survival \\
\hline Caffeine $5 \mathrm{~g} / \mathrm{L}$ & $0.78 \pm 0.64^{\mathrm{a}}$ & 0.00 \\
Caffeine $2,5 \mathrm{~g} / \mathrm{L}$ & $4.60 \pm 0.18^{\mathrm{b}}$ & 45.0 \\
Control & $5.58 \pm 0.08^{\mathrm{c}}$ & 57.5 \\
\hline
\end{tabular}

Values whith unequae letters were significantly different. 
The Tukey-Kramer test showed that the difference between the hatching means of the snails from the group treated with caffeine at $5 \mathrm{~g} / \mathrm{L}$ and the control group $(\mathrm{p}<0.001)$, from the group treated with caffeine at $5 \mathrm{~g} / \mathrm{L}$ and the group treated with $2.5 \mathrm{~g} / \mathrm{L}$ $(\mathrm{p}<0.001)$, as well as from the control group and the group treated with caffeine at $2.5 \mathrm{~g} / \mathrm{L}$ $(p<0.001)$ was significant.

The growth of the individuals was observed until the $90^{\text {th }}$ day, because on the $100^{\text {th }}$ day, the group treated with caffeine at $5 \mathrm{~g} / \mathrm{L}$ died (ANOVA; $p=0.45$ ). The difference between the means growth of the treated and the control groups was not significant.

In terms of the sexual maturity, it was not possible to observe the difference between the group treated with caffeine at $2.5 \mathrm{~g} / \mathrm{L}$ and the control group, since none of these groups laid eggs until the $120^{\text {th }}$ day.

Bessa and Araújo (1995b) observed that in $S$. octona snails, the sexual maturity was attained at
38 to 50 days after birth. During the study of these authors, the temperature varied from 23 to $26^{\circ} \mathrm{C}$. D'ávila and Bessa (2005) observed the sexual maturity of S. octona after 45-48 days of life, with temperatures ranging from $24.16^{\circ}$ to $28.72^{\circ} \mathrm{C}$. Marcus and Marcus (1968) observed that S. octona attained sexual maturity on the $109^{\text {th }}$ day, but the conditions under which this experiment was carried out were not mentioned by the authors. The present study, maximum temperature was $23.5^{\circ} \mathrm{C}$; an minimum $19.7^{\circ} \mathrm{C}$. This might have retarded the sexual development of the snails with attaining sexual maturity latter (Furtado et al., 2004).

Experiment III - The influence of caffeine and thymol on the survival, growth and reproduction of 10-day-old and 30-day-old juveniles

10-day-old juveniles treated with caffeine Caffeine affected the survival of the 10-day-old juveniles $72 \mathrm{~h}$ after being treated with it (Table 3 ).

Table 3 - Survival of Subulina octona juveniles treated with caffeine at 10 days of age.

\begin{tabular}{cccc}
\hline Time after exposition & Treatment & Survival X \pm SD & Percentual Survival \\
\hline $72 \mathrm{hrs}$ & Caffeine $5 \mathrm{~g} / \mathrm{L}$ & $7.50 \pm 0.5^{\mathrm{a}}$ & 75.0 \\
& Caffeine $2,5 \mathrm{~g} / \mathrm{L}$ & $7.00 \pm 1.4^{\mathrm{a}}$ & 70.0 \\
& Control & $9.75 \pm 0.5^{\mathrm{b}}$ & 97.5 \\
\multirow{3}{*}{120 days } & Caffeine $5 \mathrm{~g} / \mathrm{L}$ & $7.00 \pm 0.2^{\mathrm{a}}$ & 55.0 \\
& Caffeine $2,5 \mathrm{~g} / \mathrm{L}$ & $6.80 \pm 0.3^{\mathrm{a}}$ & 62.5 \\
& Control & $9.10 \pm 0.7^{\mathrm{b}}$ & 80.0 \\
\hline
\end{tabular}

Values whith unequae letters were significantly different.

The ANOVA test $(\mathrm{p}<0.05 ; \mathrm{p}=0.000)$ showed that the difference between the survival means of the individuals treated with caffeine at 5 and $2.5 \mathrm{~g} / \mathrm{L}$, as well as of those of the control group were significant. The Tukey-Kramer test showed that the difference between the survival means of the snails from the group treated with caffeine at $5 \mathrm{~g} / \mathrm{L}$ and the control group $(\mathrm{p}<0.05)$, from the group treated with caffeine at $5 \mathrm{~g} / \mathrm{L}$ and the group treated with caffeine $2.5 \mathrm{~g} / \mathrm{L}$ ( $\mathrm{p}<0.05)$, as well as from the control group and the group which was treated with caffeine at $2.5 \mathrm{~g} / \mathrm{L}(\mathrm{p}<0.01)$ was significant. However, the survival rate was higher than $60 \%$, which was the rate determined by Souza (1984) to consider a substance as being active.

The treatment with caffeine also affected the survival of the juveniles during the 120 days after the treatment (Table 3). The Tukey-Kramer test showed that the difference between the means number of snails in the group treated with caffeine at $5 \mathrm{~g} / \mathrm{L}$ and the control group $(\mathrm{p}<0.001)$, in the groups treated with caffeine at 5 and $2.5 \mathrm{~g} / \mathrm{L}$ $(\mathrm{P}<0.005)$, and in the control group and the group treated with caffeine at $2.5 \mathrm{~g} / \mathrm{L}(\mathrm{p}<0.001)$ was significant.

Souza (2003), testing the molluscicidal activity of caffeine at $1 \mathrm{~g} / \mathrm{L}$ on $S$. octona adults, found that after $24 \mathrm{~h}$ of observation the mortality rate was $70 \%$. This result disagreed with that obtained in the present study, in which the survival of $75 \%$ of the snails treated with caffeine at $5 \mathrm{~g} / \mathrm{L}$ was observed, a dose significantly superior to that employed by Souza. This discrepancy could be the result of characteristics inherent to the snails, such as the age and population of origin, which provided them with more or less resistance or even differences in the method employed in these two studies.

When observed the growth of the snails, the ANOVA test $(p<0.05 ; \mathrm{p}=0.85)$ showed that the 
difference between the means of the group treated with caffeine and the control group was not significant.

On the $115^{\text {th }}$ day the presence of eggs in the snails uterus through their transparent shell, but no egg was observed laid in the terraria until the term of the experiment. In this period, the individuals treated with caffeine $(5 \mathrm{~g} / \mathrm{L})$ had a mean shell length of $10.3 \mathrm{~mm}$, the ones treated with caffeine $(2.5 \mathrm{~g} / \mathrm{L})$ had a mean shell length of $11.4 \mathrm{~mm}$, and in the control group, the mean length was $10.4 \mathrm{~mm}$.

\section{0-day-old juveniles treated with thymol}

The treatment with thymol did not affect the survival of the 10-day-old juveniles: the survival rate was $77.5 \%$ for thymol at $5 \mathrm{~g} / \mathrm{L}, 80 \%$ for thymol at $2.5 \mathrm{~g} / \mathrm{L}$ and $100 \%$ in the control group. The ANOVA test $(\mathrm{p}<0.05 ; \mathrm{p}=0.1)$ showed that the difference between the survival means during the first $72 \mathrm{~h}$ after the treatment of the individuals with thymol at $5 \mathrm{~g} / \mathrm{L}$ and $2.5 \mathrm{~g} / \mathrm{L}$, and of those of the control group was not significant. No death was observed in these groups until the end of the experiment.

When the growth of the snails was observed, the ANOVA test $(\mathrm{p}<0.05 ; \mathrm{p}=0.85)$ showed that the difference between the means of the treated and the control groups was not significant.
There was no significant difference of attaining sexual maturity: this was attained on the $105^{\text {th }}$ day, when the presence of eggs was observed through the snails' transparent shell the presence of eggs in their uterus. However, no eggs were found in the terraria until the end of the experiment.

\section{0-day-old juveniles treated with caffeine}

The treatment with caffeine at $5 \mathrm{~g} / \mathrm{L}$ affected the survival of the 30-day-old juveniles: in this group, the survival rate was $52 \%$. The survival rate of the group treated with caffeine at $2.5 \mathrm{~g} / \mathrm{L}$ was $92.5 \%$, and that of the control group was $100 \%$. The ANOVA test $(p<0.05 ; p=0.002)$ showed that the difference between the survival means during the first $72 \mathrm{~h}$ after the treatment of the individuals with caffeine at $5 \mathrm{~g} / \mathrm{L}$ and $2.5 \mathrm{~g} / \mathrm{L}$, and of those of the control group was significant.

The Tukey-Kramer test showed that the difference between the survival means of the snails from the group which was treated with caffeine at $5 \mathrm{~g} / \mathrm{L}$ and the control group $(\mathrm{p}<0.01)$, from the group treated with caffeine at $5 \mathrm{~g} / \mathrm{L}$ and the group treated with $2.5 \mathrm{~g} / \mathrm{L} \quad(\mathrm{p}<0.01)$ was significant. The difference between the survival means of the snails from the control group and the group treated with caffeine at $2.5 \mathrm{~g} / \mathrm{L}$ was not significant (Table 4 ). After the first $72 \mathrm{~h}$, there was no death until the rest of the experiment.

Table 4 - Survival of Subulina octona jeveniles treated with caffeine at 30 days of age.

\begin{tabular}{cccc}
\hline Time after exposition & Treatment & Survival $\mathbf{X} \pm$ SD & Percentual Survival \\
\hline $72 \mathrm{hrs}$ & Caffeine $5 \mathrm{~g} / \mathrm{L}$ & $5.52 \pm 2.20^{\mathrm{a}}$ & 52.5 \\
& Caffeine $2,5 \mathrm{~g} / \mathrm{L}$ & $9.00 \pm 0.80^{\mathrm{b}}$ & 92.0 \\
& Control & $10.0 \pm 0.00^{\mathrm{b}}$ & 100 \\
\hline
\end{tabular}

Values whith unequae letters were significantly different.

When was observed the growth of the snails during the 120 days, the ANOVA test $(\mathrm{p}<0.05$; $p=0.98$ ) showed that the difference between the means of the treated and the control group was not significant. There was no significant difference in terms of attaining sexual maturity (this was attained on the 105th day), or in the number of juveniles produced by the 30-day-old group of $S$. octona: the group treated with caffeine at $5 \mathrm{~g} / \mathrm{L}$ produced 21 , the group treated with caffeine at $2.5 \mathrm{~g} / \mathrm{L}$ produced 23 , and the control group produced 26 , until the $120^{\text {th }}$ day.

\section{0-day-old juveniles treated with thymol}

The treatment with thymol at $5 \mathrm{~g} / \mathrm{L}$ affected the survival of the 30-day-old juveniles $72 \mathrm{~h}$ after the experiment (Table 5).

The Tukey-Kramer test showed that the difference between the survival means of the snails from the group treated with thymol at $5 \mathrm{~g} / \mathrm{L}$ and the control group ( $\mathrm{p}<0.01)$, and from the groups treated with thymol at $2.5 \mathrm{~g} / \mathrm{L}$ and $5 \mathrm{~g} / \mathrm{L}(\mathrm{p}<0.01)$ was significant. The difference between the survival means of the snails from the group treated with caffeine at $2.5 \mathrm{~g} / \mathrm{L}$ and the control group was not significant. 
The treatment with thymol at $5 \mathrm{~g} / \mathrm{L}$ also affected the survival of the 30-day-old juveniles during the
120 days following the exposition (Table 5, Fig. 2).

Table 5 - Survival of Subulina octona juveniles treated with thymol at 30 days of age.

\begin{tabular}{cccc}
\hline Time after exposition & Treatment & Survival $\mathbf{X} \pm$ SD & Percentual Survival \\
\hline $72 \mathrm{hrs}$ & Thymol $5 \mathrm{~g} / \mathrm{L}$ & $7.75 \pm 0.50^{\mathrm{a}}$ & 77.5 \\
& Thymol $2,5 \mathrm{~g} / \mathrm{L}$ & $9.50 \pm 0.50^{\mathrm{b}}$ & 95.0 \\
& Control & $9.50 \pm 0.50^{\mathrm{b}}$ & 97.5 \\
\multirow{3}{*}{120 days } & Thymol $5 \mathrm{~g} / \mathrm{L}$ & $6.10 \pm 5.50^{\mathrm{a}}$ & 45.0 \\
& Thymol $2,5 \mathrm{~g} / \mathrm{L}$ & $8.15 \pm 7.75^{\mathrm{b}}$ & 75.0 \\
& Control & $9.65 \pm 9.75^{\mathrm{b}}$ & 95.0 \\
\hline
\end{tabular}

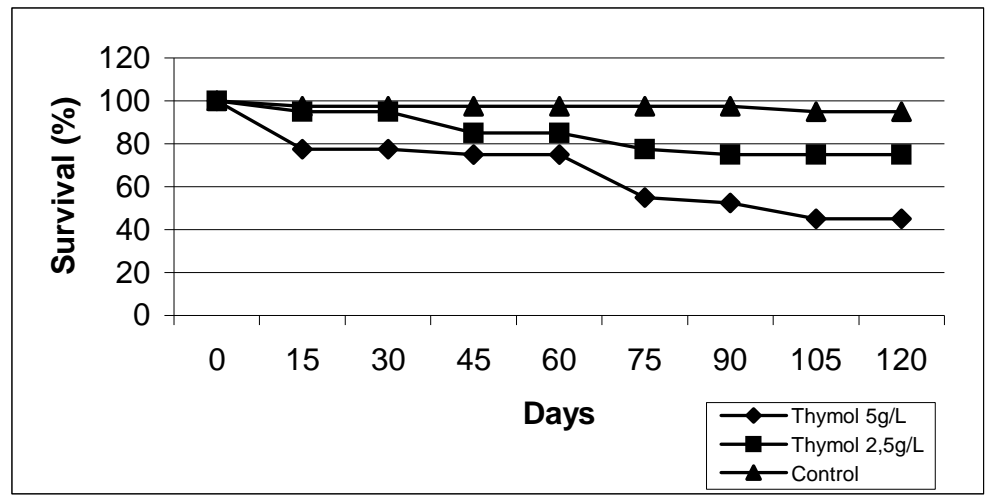

Figure 2 - Survival of Subulina octona snails treated with thymol at 30 days of age and observed for 120 days after treatment.

The Tukey-Kramer test showed that the difference between the survival means of the snails from the group treated with thymol at $5 \mathrm{~g} / \mathrm{L}$ and the control group $(\mathrm{p}<0.01)$, and from the groups treated with thymol at 5 and $2.5 \mathrm{~g} / \mathrm{L}(\mathrm{p}<0.01)$ was significant. The difference between the survival means of the snails from the group treated with caffeine at $2.5 \mathrm{~g} / \mathrm{L}$ was not significant.

These results showed that thymol influenced the survival of $S$. octona as time passed, when these were previously treated with thymol at 5 and $2.5 \mathrm{~g} / \mathrm{L}$ at 30 days of age.

The treatment with thymol did not influence the growth of the snails during the 120 days after the experiment. The ANOVA test $(\mathrm{p}<0.05 ; \mathrm{p}=0.95)$ showed that the difference between the means of the treated and the control group was not significant (Table 5).

There was no significant difference in the attaining the sexual maturity (this was attained on the 105th day), or in the number of juveniles produced by the 30-day-old group of $S$. octona: the group treated with thymol at $5 \mathrm{~g} / \mathrm{L}$ produced 21 , the group treated at $2.5 \mathrm{~g} / \mathrm{L}$ produced 24 , and the control group produced 27 juveniles, until the $120^{\text {th }}$ day. The results obtained in this experiment, suggested that other protocols should be established for the tests in the field.

\section{RESUMO}

Subulina octona é um molusco terrestre que atua como hospedeiro intermediário de parasitos. Também atua como praga agrícola. O objetivo deste trabalho foi avaliar, durante 120 dias, o efeito da cafeína e do timol a $2,5 \mathrm{~g} / \mathrm{L}$ e a $5 \mathrm{~g} / \mathrm{L}$, sobre a eclodibilidade, a sobrevivência após a eclosão, crescimento e a reprodução de $S$. octona em condições de laboratório. Foram testados 240 ovos, 240 jovens com 10 e 30 dias de vida. Os resultados dos testes mostraram que o timol $(5 \mathrm{~g} / \mathrm{L}$ e $2,5 \mathrm{~g} / \mathrm{L}$ ) e a cafeína a $5 \mathrm{~g} / \mathrm{L}$ atuaram como ovicida. Nos jovens com 10 dias de vida a cafeína à $5 \mathrm{~g} / \mathrm{L}$ provocou uma mortalidade de $25 \%$ e a $2,5 \mathrm{~g} / \mathrm{L}$ $30 \%$. O timol a $2,5 \mathrm{~g} / \mathrm{L}$ e $5 \mathrm{~g} / \mathrm{L}$ provocou 20 e $22,5 \%$ de mortalidade, respectivamente. Nos 
jovens com 30 dias de vida a cafeína a $5 \mathrm{~g} / \mathrm{L}$ causou $47,5 \%$ de mortalidade. Esses resultados sugerem novos estudos no campo.

\section{REFERENCES}

Alicata, J. E. (1940), The life cicle of Postharmostomum gallinum, the cecal flucke of poultry. J. Parasitol. 26, 135- 146.

Ash, L. R. (1962), Helminth parasites of dogs and cats in Hawaii. J. Parasitol. 48, 63-65.

Araujo, J. L. B. and Bessa, E. C. A. (1993), Moluscos de importância econômica do Brasil. II Subulinidae. Subulina octona (Brugüiére, 1789) (Mollusca, Gastropoda, Pulomonata, Stylommatophora). Revta. Bras. Zool. 10, 489- 497.

Bessa, E. C. A. and Araújo, J. L. B. (1995a), Oviposição, tamanho de ovos e medida do comprimento da concha em diferentes fases do desenvolvimento de Subulina octona (Brugüére, 1789) (Pulomonata, Subulinidae) em condições de Laboratório. Revta. Bras. Zool. 12, 647654.

Bessa, E. C. A. and Araújo, J. L. B. (1995b), Ocorrência de autofecundação em Subulina octona (Brugüére, 1879) (Pulmonata, Subulinidae) em condições de laboratório. Revta. Bras. Zool. 12, 719- 723.

Bessa, E.C.A., Lima, W.S., Daemon, E. Cury.M.C., and J.L.B. Araújo. 2000. Desenvolvimento biológico de Angiostrongylus vasorum (Baillet) Kamensk (Nematoda, Angiostrongylidae) em Subulina octona (Mollusca, Subulinidae) em condições de laboratório. Revta. Bras. Zool. 17(1): 29-41.

Bezerra, P., Fernandes, A. G., Craveiro, A. A., Andrade, C. H. S., Matos, F. J. A., Alencar, J. W., Machado, M. I. L., Viana, G. S. B., Matos, F. F. and Rouquayrol, M.Z. (1981), Composição química e atividade de óleos essenciais de plantas do nordeste - Gênero Lippia. Ciência and Cultura, 33, 1-14

Brenelli, E. C. S. (2003), A extração de cafeína em bebidas estimulantes - uma nova abordagem para um experimento clássico em química orgânica. Quím. Nova, 26, 136- 138.

Brandolini, S. P., Amato, S. B. and Pereira, A. A. (1997), Relacionamento de Tanaisia bragai (Digenea, Eucotylidae) e seu hospedeiro intermediário, Subulina octona (Gastropoda, Subulinidae) sob condições experimentais. Parasit. al día, 21 (3-4): 1-7.

Budavari, S. (1989), The Merck index - An encyclopedia of chemicals, drugs and biologicals. $17^{\text {th }}$ edition, Rahway, Merck and Co., Inc.

D`ávila, S. and Bessa, E. C. A. (2005), Influência do substrato sobre a reprodução de Subulina octona (Brugüère) (Mollusca, Subulinidae), sob condições de laboratório. Revta. Bras. Zool. 22, 197-204.

Duarte, M. J. F. (1980), O ciclo evolutivo de Postharmostomum gallinum Witenberg, 1923, no
Estado do Rio de Janeiro, Brasil (Trematoda, Brachylaemidae). Revta. Bras. Biol. 40, 783-809.

Furtado, M. C. V., Bessa, E. C. A. and Castañon, M. C. M. N. (2004), Ovoteste de Bradybaena similaris (Férussac, 1821) (Mollusca, Xanthonychidae): histologia e produção de gametas. Revta. Bras. Zoociênc., 6, 7-18.

Hollingsworth, R. G., Armstrong, J. W. and Campbell, E. (2002), Caffeine as a repellent for slugs and snails. Nature, 417, 915-916.

Marcus, E. and Marcus, E. (1968), Uber einige Subulinidae (Pulmonata) von São Paulo. Beitr. Neotrop. Fauna, 5, 186-206.

Maldonado, J. F. (1945), The life cicle of Tamerlania bragai Santos, 1934 (Eucolydae) a kidney flucke of domestic pigeons. J. Parasitol. 31, 306-314.

Okazaki, K., Kawazoe, K. and Takaishi, Y. (2002) Human platelet aggregation inhibitors from thyme (Thymus vulgaris L.). Phytother. Res. 16, 398-399.

Pereira, J. P. and Souza, C. P. (1974), Ensaios preliminares com "Anacardium occidentale" como moluscicida. Ciência e Cultura, 26, 1054-1057.

Salgueiro L. R., Cavaleiro,C., Gonçalves, M.J. and Proença da Cunha, A. (2003), Antimicrobial activity and chemical composition of the essencial oil of Lippia graveolens from Guatemala. Planta médica, 69, 80-83.

Sing, S., Singh, V. K., and Sing, D. K. (1997), Molluscicidal activity of some common spice plants. Biol. Agric. Hostic. 14, 237-249.

Souza, H. E. (2003), Atividade moluscicida $e$ fagoinibidora da cafeína e do timol sobre três espécies de moluscos gastrópodes terrestres em condições de laboratório. Dissertação de Mestrado, Universidade Federal de Juiz de Fora, Juiz de Fora, Brasil. 55p.

Souza, C. P.; Azevedo, M. L. L., Lopes, J. L. C., Sarti, S. J.; Filho, D. S., Lopes; J. N. C., Vichnewski, V.; Nasi, A. M. T. T. and Leitão-filho, H. F. (1984), Quimioprofilaxia da esquistossomose: atividade moluscicida de produtos naturais - ensaios com caramujos adultos e desovas. Anais da Academia Brasileira. 56, 333-338.

Souza, C. P.; Mendes, N. M.; Araújo, N. and Katz, N. (1987), Atividade moluscicida do extrato butílico de Phytolaca dodecandra sobre Biomphalaria glabrata. Mem. Inst. Oswaldo Cruz. 82, 345-359.

Vasconcellos, M. C., Santos, J. A. A., Silva, I. P., Lopes, F. E. F., Schall, V. T. (2003), Molluscicidal activity of crown of christ (Euphorbia splendens var. hislopii) (Euphorbiacea) latex submitted to $\mathrm{pH}$ variation. Braz. Arch. Biol. Tecnol. 46, 415-429.

Wicht, M. J., Haak, R., Schütt-Gerowitt, H., Kneist, S. and Noack, M.J. (2004), Suppression of caries-related microorganisms in dentine lesions after short-term chlorhexidine or Antibiotic treatment. Caries Res. 38, 436-441.

Received: December 06, 2006; Revised: July 12, 2007; Accepted: August 19, 2008. 